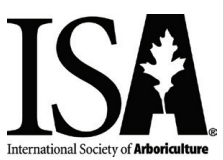

Arboriculture \& Urban Forestry 2017. 43(6):205-216

\title{
Relative Susceptibility Among Arborvitae Cultivars to Arborvitae Leafminer, Argyresthia thuiella (Lepidoptera: Argyresthiidae)
}

\author{
Fredric Miller and Donna Danielson
}

Abstract. Eighteen Thuja species and cultivars were evaluated for ovipositional preference for, and relative susceptibility to, feeding by the arborvitae leafminer. Thuja occidentalis 'Hetz Midget' and 'Hoopesii' were least susceptible; T. occidentalis cultivars 'Gracilis', 'Holmstrup', 'Spiralis', and 'Techny', and T. plicata 'Fastigiata', were intermediate in susceptibility; Thuja occidentalis cultivars 'Aurea', 'Douglasii Aurea', 'Globosa', 'Hetz Wintergreen', 'Smaragd', 'Umbraculifera', 'Wagneri', 'Wareana,' and 'Waxen', and species T. occidentalis, and T. plicata, were highly susceptible to ALM feeding. Short trees suffered significantly less feeding compared to tall trees, with number of infested branch tips (IBTs) increasing with tree height. Short trees $(<4 \mathrm{~m})$ had significantly more feeding damage in the upper canopy zone and tall trees $(>4$ $\mathrm{m}$ ) had greater damage in the lower and middle zones. Trees with very dense canopies had significantly fewer IBTs compared to trees with sparse, medium, and dense canopies, with IBTs decreasing as canopy density increased. There were no significant associations between number of IBTs and canopy aspect. Plant height, growth habit, and canopy zone and density appear to influence infestation levels and possibly ovipositional preference. These findings suggest some important ALM management guidelines for the nursery and landscape industries.

Key Words. Arborvitae; Arborvitae Leafminer; Argyresthia thuiella; Insect Ovipositional Preference; Susceptibility; Thuja.

The arborvitae leafminer (ALM) [Argyresthia thuiella (Pack.)] is a native insect pest of arborvitae (Thuja spp.). Heavy ALM infestations can kill foliage, weaken trees, give the trees a bleached, thin, unattractive appearance, and may make them more susceptible to secondary agents such as wood-boring insects and foliar diseases. Heavily infested trees can be killed.

ALM is a univoltine, yponomeutoid moth (Lepidoptera: Argyresthiidae). Adults are small (about six mm long) and light gray with brown and black spots, and have long, slender antennae, and pale brown legs and abdomen. The wingspread is about eight $\mathrm{mm}$. The larvae are 0.75 to $3 \mathrm{~mm}$ long, green or brown with a black head. In North America, arborvitae leafminer is found from the New England area and in eastern Canada south to the mid-Atlantic states and west to Missouri, U.S. (Davidson and Raupp 2010; Maier et al. 2011). ALM is also known to occur in Europe (i.e., the Netherlands, Austria, and Germany), and an isolated population is also found in British Columbia, Canada (Busck 1907). Other leafminer species attacking arborvitae include the Canadian arborvitae leafminer (A. canadensis) and the brown arborvitae leafminer (Coleotechnites thujaella), which both feed on northern white cedar and are common in the northeastern United States, and the cypress tipminer (A. cupressella), which feeds on cypress in the western U.S. Argyresthia freyella is common to North America and feeds on eastern red cedar (Cranshaw 2004; Davidson and Raupp 2010; Maier et al. 2011).

The only known host is arborvitae. After eggs hatch, larvae mine the leaves, basipetally killing up to three centimeters of foliage (Rose and Lindquist 1982). Mined leaves first turn yellow, then brown and dry, and may fall off. Leaf-mining injury begins to appear in summer with extensive damage obvious by autumn and the following spring. ALM overwinters as larvae, and resume feeding in spring. Exit holes are chewed just prior to pupation within mined foliage in late spring, with the pupa facing the exit hole. ALM adults start to emerge in early 
summer (533 to $700 \mathrm{DD}_{50}$ ) (Adams 2015), mate, and females lay eggs in axils of branchlets or along leaf margins. There is one generation per year (Busck 1907; Davidson and Raupp 2010; Maier et al. 2011).

Thuja occidentalis L. (American arborvitae) is native to the eastern United States and the Great Lakes area, and T. plicata Donn ex D. Don (western red cedar) is native to the Pacific Northwest region. Both are important timber species, used primarily for shingles, shakes, siding, and poles. Both species, and hybrids of these with other species (e.g., T. standishii), include a number of small- to medium-sized evergreens valued for midwestern, eastern, and western landscaping. Thuja occidentalis cultivars 'Smaragd', 'Nigra', and 'Techny' in particular have high landscape value because of their dense growth and ability to maintain green foliage color in all seasons (Dirr 2009). Cultivars also have diverse growth habits and leaf color, including dwarf, round, globe, and narrow-upright forms with yellow, blue, and various shades of green foliage (Dirr 2009). Arborvitae tolerate a wide range of soil and climate conditions, thriving in fertile, well-drained, moist soil and full sun, but they can also do well in light shade and somewhat dry locations. Thuja plicata is more shade-tolerant than T. occidentalis or T. (Platycladus) orientalis. Arborvitae is commonly used as screens, windbreaks, groupings, accent plants, and boundary hedges (Dirr 2009).

The relationship between adult female leafminer oviposition and larval survival is essential in understanding leafminer population dynamics. Since most adult Lepidopteran leafminers do not feed, ovipositional site selection by the female should be driven by larval survival and fecundity and not by adult feeding preference, as is common by free-feeding insect herbivores (Auerbach and Simberloff 1989; Faeth 1991). In addition, being of limited mobility, larval leafminers are restricted to the area near where the adult female lays her eggs. Eggs laid on an unsuitable host, the wrong part of the host, or on a secondary host could negatively affect larval development and survival. It is reasonable to expect a positive correlation between ovipositional preference and larval performance. However, according to Kagata and Ohgushi (2001), this is not always the case, even with leafminers.
The unique larval strategy of feeding inside the leaf (Auerbach et al. 1995; Connor and Taverner 1997) provides protection from various natural enemies, including the physical environment (e.g., rain, dew), some predators and parasitoids, premature leaf abscission, and some host-plant defenses (waxy cuticle) compared to external feeding herbivores. As an univoltine insect, ALM spends the majority of the leafmining larval stage inside foliage (Davidson and Raupp 2010; Cornell Extension 2012) and probably experiences minimal, if any, exposure to these natural enemies. In order to better understand the ovipositional preferences and relative susceptibility of Thuja spp., a study was initiated in the summer of 2000. The objectives of the study were to determine: ALM ovipositional preference on arborvitae species and cultivars; susceptibility of arborvitae species and cultivars to ALM feeding; what role, if any, plant growth characteristics (i.e., growth habit, height, canopy zone, density, and aspect) have in ALM ovipositional preference, and to provide monitoring and management guidelines for nursery growers and landscape management professionals.

\section{MATERIALS AND METHODS}

The study area was located in a 1.21 hectare arborvitae collection at The Morton Arboretum in Lisle, Illinois, U.S. The Morton Arboretum's plant records indicate the study trees were planted between 1924 and 1973, and were approximately 30 - to 80 -years-old at the time of the study. There was no history of insecticide treatment, and all plants within a cultivar and/or species were approximately equal in height. The arborvitae leafminer (A. thuiella) was the only leafminer species present.

An ALM infestation was first observed in the collection in 1998 during routine plant health care (PHC) scouting. By summer of 2000, the infestation had become more extensive and severe, with numerous adults observed (first seen at $702 \mathrm{DD}_{50}$ accumulations starting $01 \mathrm{March}$ ) in the collection. Beginning in late summer 2000, a field study was initiated to evaluate the relative preference among Thuja species and cultivars for ALM oviposition and feeding. Study trees varied in height from $0.6 \mathrm{~m}$ to $12 \mathrm{~m}$ and had globose, pyra- 
midal, or columnar growth habits. Arborvitae study trees consisted of a species and cultivars (15) of American arborvitae and species and one cultivar of western arborvitae or western red cedar. Depending on availability, three to four single-tree replicates per species/cultivar were evaluated, with the exception of 'Hetz Midget', where five trees were used due to their small size $(<1 \mathrm{~m}$ in height). A total of 67 arborvitae trees were included in the study. Table 1 contains a complete list of species/cultivars evaluated.

Larval feeding damage was evaluated by species/cultivar, location in the canopy zone (lower, middle, upper), tree height (short or tall), tree growth habit (globose, columnar, pyramidal), foliage density (sparse to very dense), and cardinal direction (N, S, E, W). One branch sample, 20 $\mathrm{cm}$ long, was randomly selected from each of the four cardinal directions of each study tree at $1 \mathrm{~m}, 4$ $\mathrm{m}$, and $>4 \mathrm{~m}$ above ground level. For trees shorter than $4 \mathrm{~m}$, samples were taken at $30 \mathrm{~cm}, 1 \mathrm{~m}$, and approximately $3 \mathrm{~m}$. A total of 645 branch samples were taken from all study trees in the collection from 07 August 2000 through 06 February 2001. An additional 719 samples were taken in summer of 2001. For trees above $4 \mathrm{~m}$, a bucket truck was used to collect samples from portions of the tree canopy too high to reach with pole pruners.

Branch samples collected in the field were brought back to the lab for inspection, where the total number of infested and non-infested branch tips was counted and recorded. The percent infested branch tips (IBTs) was calculated by dividing the number of infested tips by the total number of tips per branch. Percent IBTs was used as a proxy for comparing relative susceptibility among cultivars.

Concurrent with branch sampling, each study tree was visually categorized for shape (globose, columnar, or pyramidal), height (short $\leq 4 \mathrm{~m}$, tall $\geq 4 \mathrm{~m}$ ), and canopy density (very dense, dense, medium, or sparse). Canopy density was determined visually by observing the amount of light passing through the sprays and by measuring the depth of branching from the perimeter of the canopy (tip of sprays) into the interior of the plant. Differences in canopy density were very obvious to the naked eye, particularly for the very dense cultivars. In an attempt to estimate canopy density for both very dense and sparse cultivars, a few informal light penetration measurements were taken using a portable light meter $\left(\right.$ Extech $^{\circledR}$ wide-range light meter-EA30, Extech Instruments, Waltham, Massachusetts, U.S.). The light meter was handheld inside the plant interior and amount of light penetrating the tree canopy was measured (data not shown). A standard ruler was used to measure (nearest $\mathrm{cm}$ ) the linear distance from the spray tip to where foliage ended within the tree interior (data not shown).

Table 1. Arborvitae (Thuja spp.) species/cultivars evaluated by tree height, canopy density, and growth habit.

\begin{tabular}{|c|c|c|c|}
\hline Species/Cultivar & $\begin{array}{l}\text { Tree } \\
\text { height }^{z}\end{array}$ & $\begin{array}{l}\text { Canopy } \\
\text { density }^{y}\end{array}$ & $\begin{array}{l}\text { Growth } \\
\text { habit }^{\mathrm{x}}\end{array}$ \\
\hline T. occidentalis & $\mathrm{T}$ & SP & PYR \\
\hline T. occidentalis 'Aurea' & $\mathrm{S}$ & SP & PYR \\
\hline T. occidentalis 'Douglasii Aurea' & $\mathrm{T}$ & SP & PYR \\
\hline T. occidentalis ‘Globosa’ & $\mathrm{S}$ & DEN & GLOB \\
\hline T. occidentalis ‘Gracilis' & $\mathrm{S}$ & DEN & GLOB \\
\hline T. occidentalis 'Hetz Midget' & $\mathrm{S}$ & VDEN & GLOB \\
\hline T. occidentalis 'Hetz Wintergreen' & $\mathrm{T}$ & MED & PYR \\
\hline T. occidentalis 'Holmstrup' & $\mathrm{S}$ & VDEN & $\mathrm{COL}$ \\
\hline T. occidentalis 'Hoopesii' & S & DEN & GLOB \\
\hline T. occidentalis 'Smaragd' & $\mathrm{T}$ & DEN & COL \\
\hline T. occidentalis 'Spiralis' & $\mathrm{T}$ & DEN & PYR \\
\hline T. occidentalis 'Techny' & $\mathrm{S}$ & DEN & PYR \\
\hline T. occidentalis 'Umbraculifera' & S & DEN & GLOB \\
\hline T. occidentalis 'Wagneri' & S & DEN & GLOB \\
\hline T. occidentalis 'Wareana' & $\mathrm{S}$ & DEN & PYR \\
\hline T. occidentalis 'Waxen' & $\mathrm{T}$ & DEN & PYR \\
\hline T. plicata & $\mathrm{T}$ & DEN & PYR \\
\hline T. plicata 'Fastigiata' & $\mathrm{T}$ & DEN & PYR \\
\hline
\end{tabular}

${ }^{z}$ Tree height: $\mathrm{S}=$ short; $\mathrm{T}=$ tall.

${ }^{\text {y }}$ Canopy density: SP = sparse canopy; MED = medium canopy; DEN = dense canopy; VDEN = very dense and compact canopy.

${ }^{x}$ Growth habit: GLOB = globose; $\mathrm{PYR}=$ pyramidal; $\mathrm{COL}=$ columnar. 


\section{Statistical Analysis}

Measures of defoliation as a function of mean percent infested branch tips (MIBTs) for tree height, growth habit, cardinal direction, and canopy density, were subjected to analysis of variance (ANOVA) using cultivar as the main effect. Percent infested branch tips (IBTs) were arcsine transformed before analysis to correct for non-normality. Where significance was found, means were compared with a Student-NewmanKeuls (SNK) multiple comparison test. Where significant, a Pearson Product Moment correlation analysis was performed in some cases. All data are presented as means \pm standard error (SEM). All data were analyzed using SigmaStat for Windows ${ }^{\oplus}$ (Jandel Scientific 1992). Data and analyses are shown in Table 2 through Table 8.

\section{RESULTS}

\section{Species/Cultivar}

Significant differences $(\mathrm{F}=18.8 ; P<0.001)$ for MIBTs were found among cultivars (Table 2). Thuja occidentalis 'Hetz Midget' and 'Hoopesii' showed significantly fewer IBTs $(3 \% \pm 0.6)$ compared to all other species/cultivars. Thuja occidentalis 'Holmstrup', T. plicata 'Fastigiata', T. occidentalis 'Spiralis', T. occidentalis 'Gracilis', and T. occidentalis 'Techny' were intermediate in infestation with $10 \%-20 \%$ IBTs. Thuja occidentalis cultivars 'Aurea', 'Douglasii Aurea', 'Globosa', 'Hetz Wintergreen', 'Wagneri', 'Wareana', and T. plicata had between $20 \%$ and $29 \%$ IBTs. Trees with the greater than $30 \%$ IBTs included the straight species T. occidentalis, and T. occidentalis cultivars 'Umbraculifera' and 'Waxen'. The cultivar T. occidentalis 'Smaragd' was highly infested with $42 \%$ IBTs.

\section{Tree Height}

There was a highly significant difference $(\mathrm{F}=$ 5.8; $P<0.001)$ between IBTs on short trees $(<4 \mathrm{~m})$ versus tall trees $(>4 \mathrm{~m})$ (Table 3$)$. Short trees had significantly less damage ( $16 \%$ infested tips) compared to tall trees (24\% infested tips). In addition, there was a weak but significant direct correlation $\left[\mathrm{R}^{2}=0.36, P=0.009, \mathrm{IBT}=4.82+\right.$ $(12.91 \times$ tree height $)]$ between tree height and IBTs. The Morton Arboretum's plant records indicated that all of the plants in the study were well-established, having been planted between 30 and 80 years prior to this study, and that plants within a given cultivar and/or species were of approximately the same height.

Table 2. Mean percentage infested branch tips (IBTs) for all species/cultivar, 2000-2001 \pm SEM.

\begin{tabular}{ll}
\hline Taxa & Mean \% infested branch tips \\
\hline T. occidentalis & $36 \mathrm{~d} \pm 2.75$ \\
T. occidentalis 'Aurea' & $23 \mathrm{c} \pm 1.76$ \\
T. occidentalis 'Douglasii Aurea' & $29 \mathrm{c} \pm 3.05$ \\
T. occidentalis 'Globosa' & $22 \mathrm{c} \pm 2.36$ \\
T. occidentalis 'Gracilis' & $16 \mathrm{~b} \pm 1.96$ \\
T. occidentalis 'Hetz Midget' & $3 \mathrm{a} \pm 0.60$ \\
T. occidentalis 'Hetz Wintergreen' & $21 \mathrm{c} \pm 1.93$ \\
T. occidentalis 'Holmstrup' & $11 \mathrm{~b} \pm 1.71$ \\
T. occidentalis 'Hoopesii' & $6 \mathrm{a} \pm 0.76$ \\
T. occidentalis 'Smaragd' & $42 \mathrm{~d} \pm 2.42$ \\
T. occidentalis 'Spiralis' & $14 \mathrm{~b} \pm 1.07$ \\
T. occidentalis 'Techny' & $19 \mathrm{~b} \pm 2.14$ \\
T. occidentalis 'Umbraculifera' & $31 \mathrm{~cd} \pm 3.07$ \\
T. occidentalis 'Wagneri' & $20 \mathrm{c} \pm 1.78$ \\
T. occidentalis 'Wareana' & $21 \mathrm{c} \pm 1.13$ \\
T. occidentalis 'Waxen' & $31 \mathrm{~cd} \pm 1.90$ \\
T. plicata & $29 \mathrm{c} \pm 2.70$ \\
T. plicata 'Fastigiata' & $15 \mathrm{~b} \pm 1.47$ \\
\hline
\end{tabular}

${ }^{2}$ Values within columns followed by the same letter are not significantly different $(P<0.05$, Student-Newman-Keuls multiple comparison test).

Table 3. Mean percent infested tips (IBTs) for all species/ cultivars by plant height, 2000-2001 \pm SEM.

\begin{tabular}{ll}
\hline Tree height & $\%$ infested tips $^{z}$ \\
\hline Short & $16 \mathrm{a} \pm 1.24$ \\
Tall & $24 \mathrm{~b} \pm 0.67$ \\
\hline${ }^{z}$ Values within columns followed by the same letter are not significantly \\
different $(P<0.05, \mathrm{t}$-test $)$.
\end{tabular}

\section{Canopy Zone}

There was only a slight but statistically significant $(\mathrm{F}=4.0 ; P=0.003)$ difference in IBTs between the upper canopy zone (21\% infested tips) and the lower canopy zone (25\% infested tips). The middle zone was intermediate (24\%) in IBTs (Table 4).

\section{Height and Zone of Tree}

When comparing infestation levels among tall and short trees among three canopy zones, short trees had a mean of $8 \%$ fewer IBTs compared to taller trees with significant differences $(\mathrm{F}=14.3 ; P<$ $0.001)$ among height and zone classes. Short trees $(<4 \mathrm{~m})$ had significantly more damage in the upper zone $(24 \%)$ and tall trees had greater damage, $30 \%$ and $26 \%$, in the lower and middle zones, re- 
spectively. Short and tall arborvitae had the least tip damage ( $15 \%$ to $21 \%$ ) in the lower and middle zones, and upper zones, respectively (Table 5).

\section{Growth Habit}

There were significant differences in damage severity related to tree growth habit (Table 6). Globularshaped trees had significantly $(\mathrm{F}=11.0 ; P<$ $0.001)$ less damage (17\%) compared to trees with columnar or pyramidal growth habits (24\%).

\section{Canopy Density}

Trees with very dense canopies had significantly ( $\mathrm{F}=12.1 ; P<0.001)$ fewer infested branch tips (8\%) compared to those with sparse, medium, and dense canopies (23\%-26\% IBTs). There was a weak inverse correlation between IBTs and canopy density $\left[\mathrm{R}^{2}=0.23, P=0.047, \mathrm{BTD}=\right.$ 36.009 - (5.634 $\times$ Canopy Density)] with IBTs decreasing as canopy density increased (Table 7).

\section{Canopy Aspect}

There was no significant relationship between canopy aspect and infestation severity. In this study, the researchers could not detect a preference in arborvitae leafminer for any particular side of the tree (Table 8).

Table 4. Mean percent infested branch tips (IBTs) for all species/cultivars by tree canopy zone, 2000-2001 \pm SEM.

\begin{tabular}{ll}
\hline Canopy zone & Mean \% infested branch tips ${ }^{\mathrm{z}}$ \\
\hline Low & $25 \mathrm{~b} \pm 0.66$ \\
Middle & $24 \mathrm{ab} \pm 0.58$ \\
Upper & $21 \mathrm{a} \pm 0.57$ \\
\hline
\end{tabular}

${ }^{z}$ Values within columns followed by the same letter are not significantly different $(P<0.05$, Student-Newman-Keuls multiple comparison test).

Table 5. Mean percent infested branch tips (IBTs) by tree height and canopy zone for all species/cultivars, 2000-2001 \pm SEM.

\begin{tabular}{ll}
\hline Tree height and canopy zone & Mean \% infested branch tips ${ }^{z}$ \\
\hline Short - Low & $15 \mathrm{a} \pm 1.79$ \\
Short - Middle & $16 \mathrm{a} \pm 1.78$ \\
Short - Upper & $24 \mathrm{bc} \pm 6.31$ \\
$\quad$ & 18 \\
& \\
Mean & $30 \mathrm{c} \pm 1.32$ \\
Tall - Low & $26 \mathrm{c} \pm 1.23$ \\
Tall - Middle & $21 \mathrm{~b} \pm 0.96$ \\
$\quad$ & 26 \\
\hline
\end{tabular}

${ }^{z}$ Values within columns followed by the same letter are not significantly different $(P<0.05$, Student-Newman-Keuls multiple comparison test).
Table 6. Mean percent infested branch tips (IBTs) for all species/cultivars by growth habit, 2000-2001 \pm SEM.

\begin{tabular}{ll}
\hline Growth habit & Mean \% infested branch tips \\
\hline Globular & $17 \mathrm{a} \pm 0.71$ \\
Columnar & $24 \mathrm{~b} \pm 1.41$ \\
Pyramidal & $24 \mathrm{~b} \pm 1.72$ \\
\hline${ }^{2}$ Values within columns followed by the same letter are not significantly dif- \\
ferent $(P<0.05$, Student-Newman-Keuls multiple comparison test).
\end{tabular}

Table 7. Mean percent infested branch tips (IBTs) for all species/cultivars by canopy density, 2000-2001 \pm SEM.

\begin{tabular}{ll}
\hline Canopy density & Mean \% infested branch tips ${ }^{z}$ \\
\hline Sparse & $26 \mathrm{~b} \pm 1.78$ \\
Medium & $23 \mathrm{~b} \pm 0.88$ \\
Dense & $23 \mathrm{~b} \pm 1.00$ \\
Very dense & $8 \mathrm{a} \pm 1.12$ \\
\hline${ }^{2}$ Values within columns followed by the same letter are not significantly dif- \\
ferent $(P<0.05$, Student-Newman-Keuls multiple comparison test).
\end{tabular}

Table 8. Mean percentage infested branch tips for all species/cultivars by canopy aspect, 2000-2001 \pm SEM.

\begin{tabular}{ll}
\hline Canopy aspect & Mean \% infested branch tips ${ }^{2}$ \\
\hline North & $21 \mathrm{a} \pm 1.11$ \\
South & $24 \mathrm{a} \pm 1.23$ \\
East & $22 \mathrm{a} \pm 1.20$ \\
West & $23 \mathrm{a} \pm 1.28$ \\
\hline
\end{tabular}

${ }^{2}$ Values within columns followed by the same letter are not significantly different $(P<0.05$, Student-Newman-Keuls multiple comparison test).

\section{DISCUSSION}

Results from this study suggest that plant height, growth habit, canopy zone, and density influence ALM ovipositional preference, judging from significant differences in levels of foliar damage.

\section{Host Plant Characteristics}

The results from this study suggest that canopy density appears to play a role in ovipositional preference by ALM. Short, globe-shaped plants with very dense or dense canopies, such as 'Hetz Midget' and 'Hoopesii', had very low infestation levels ( $<7 \%$ IBTs) compared to significantly higher infestation levels (10\%-42\% IBTs) for pyramidaland columnar-shaped species and cultivars. In addition, a weak but significant inverse relationship exists between canopy density and IBTs.

While these two cultivars had lower levels of IBTs, it is not clear what factors may influence insect distribution within the tree canopy, including the insect's mobility, interspecific and intraspecific competition, natural enemies, 
micro-climate, nutritional quality of foliage, and leaf production and leaf phenology of the host trees (Brown et al. 1997). The purpose of this study was to document the relative susceptibility of arborvitae species/cultivars to ALM. Identifying a specific factor or factors responsible for differences in feeding damage was determined to be beyond the scope of this study. However, the study authors would be remiss for not offering possible suggestions for observed differences in ALM feeding damage between arborvitae species/cultivars.

Numerous studies have revealed a variety of factors responsible for differences in ovipositional and feeding preference among insect herbivores, such as leafminers, including across natural light gradients. However, these studies have primarily focused on shaded plants or plants growing in full sun, not canopy density (Moore et al. 1988, and references therein; Bentz 2003; Connor 2006). To the best of the authors' knowledge, no definitive studies have been conducted on the effect of canopy density on ovipositional preference, particularly on leafminers feeding on evergreen trees. Numerous studies of the effects of light-gradient on oviposition and host susceptibility are conflicting at best. Some herbivores are more abundant or damaging on plants in sunny areas, while others are more abundant or cause more damage in shaded environments. Bultman and Faeth (1988) showed that densities of two leafminer species feeding on Emory oak (Quercus emoryi) were negatively correlated with solar radiation, and they further concluded that even subtle differences in shading influences leafminer density and mortality. Further still, in some studies, no difference in feeding or abundance was found between sun and shade environments (Collinge and Louda 1988; Collinge and Louda 1989; Potter 1992; Connor 2006). It is possible, though not confirmed in this study, that light levels may impact ovipositional preference and susceptibility when comparing plants with very dense foliage compared to sparsely foliated plants. Dirr (2009) stated that short, globe-shaped arborvitae cultivars, such as 'Hetz Midget' and 'Hoopesii', tend to have shorter internodes and denser canopies compared to taller trees. Informal field measurements indicate short cultivars with very dense, thick foliage (e.g., 'Hoopesii') had approximately 50\% less light penetration compared to tall cultivars with sparse foliage (e.g., 'Smaragd'). In addition to diminished light penetration, short, very dense cultivars had thick foliage with branching extending approximately $8 \mathrm{~cm}$ into the canopy interior, while sparse cultivars had much thinner foliage and less branching, extending approximately $3 \mathrm{~cm}$ from the spray tip into the interior tree canopy.

Female leafminer ovipositional behavior may also be a factor. Connor (2006) indicated that daytime fliers discriminate between sun and shade foliage, while nighttime fliers do not. While not confirmed in this study, it might be inferred that female ALMs, being daytime fliers, may discriminate by preferring to oviposit on foliage receiving more sunlight. This might explain why there was significantly higher tip damage in the upper canopies of shorter cultivars, and middle and upper portions of taller cultivars.

Leaf thickness, toughness, water content, secondary compounds, and nutritional compounds have all been implicated at one time or another as possible factors responsible for various feeding patterns observed in insect herbivores (Connor 2006, and references therein). While none of these factors were directly measured in this study, field and laboratory visual observations at the time of IBT assessments indicated no obvious and/or discernable differences in leaf thickness for the arborvitae cultivars studied. In virtually all of the IBT assessments, only one larva was found per leaf tip, and only in very rare cases were two larvae discovered. This suggests there was adequate food (i.e., parenchyma tissue) for larval development for all species and cultivars in this study, regardless of canopy density. However, more formal laboratory and field studies would be required to support these findings.

The potential impact of very dense foliage versus sparse foliage on natural enemy habitat was not included in this study. Predation and parasitism are inconsistent at best. Some studies have shown higher rates of arthropod predation and parasitism in shaded areas and by canopy aspect (Trumbule and Denno 1995; Pottinger and LeRoux 1971). In contrast, a study by Bultman and Faeth (1988) on four leafminer species on Emory oak discovered that one of the species had higher survivorship on shaded trees due to higher levels of parasitism on sun trees. Further, Barrett (1994) 
found higher levels of spotted tentiform leafminers (Phyllonorycter blancardella) and apple blotch leafminers ( $P$. crataegella) in the lower to middle canopy of apple trees while parasitoid activity was more evenly distributed throughout the canopy with a trend for higher parasitism in the middle to upper canopy regions. While no infested foliage was held for parasitoid emergence, examination of infested tips and ALM larvae during field and laboratory IBT assessments did not reveal any obvious and/or discernable evidence of parasitism, suggesting natural enemies were not a significant factor in contributing to differences in IBTs across cultivars.

The remaining 16 cultivars exhibited a gradation of damage from moderate $(10 \%-20 \%$ branch tip damage) to severe ( $>20 \%$ branch tip damage). Observations in the current study are somewhat consistent with at least one other report noting pyramidal, globose, and golden arborvitae seem to be preferred, in that order (NCSU 2015). However, in this study, it is unclear why 'Globosa' and 'Umbraculifera'-both of which are short, globose, and have dense canopies-had high levels of damage (22\% and $31 \%$, respectively). Apparently, other factors are contributing to ovipositional preference with these two cultivars.

In addition to plant height, height above ground also appears to influence ovipositional preference. Non-random distribution of leafminers is common among plants and among leaves within a given plant (Cornelissen and Stiling 2008). Findings in the current study suggest that adult female ALMs prefer to oviposit in a narrow range within the tree canopy, judging from the higher-level feeding damage observed at three to five meters above ground, which corresponds to the lower and middle canopy zones of tall trees and the upper canopy zone of short trees. Shorter trees tended to be noticeably less infested, with the highest levels of injury near the top of the canopy, and taller trees had generally higher levels of infestation particularly in the lower and middle sections of the canopy.

These findings are consistent with a study by Miller and Ware (2014) in which percent leaf area consumed by elm leafminer larvae (Fenusa ulmi) was greater in the lower exterior zones of medium-sized (5-7 m) elm trees. Barrett (1994) found the mean number of spotted tentiform leafminers and apple blotch mines per leaf were generally greater in the lower-middle canopy regions of apple trees compared to upper canopy regions. Auerbach et al. (1995) observed ovipositing $P$. tremuloidella female leafminers prefer small quaking aspen trees for oviposition.

A possible explanation for higher ALM tip damage in the middle and upper zones of arborvitae trees may be partially explained by Brown et al.'s (1997) hypothesis on lack of movement and egg depletion. In studying a leaf-mining moth (Cameraria hamadryadella) on oak (Quercus spp.), Brown et al. (1997) suggested higher leafminer densities on foliage in the lower oak tree crown may be due to the lack of other potential causal factors and due to the fact that the insect overwinters in the leaf litter. Females begin ovipositing on foliage closest to overwintering, emergence, and resting sites. While density of C. hamadryadella, in the lower crown of oaks conflicts with the current study's findings, Brown et al. (1997) further stated this same hypothesis could also account for vertical stratification for insects more abundant in the upper tree crown. This hypothesis is supported by studies by Stark (1952; 1958), of a leaf-mining weevil (Recurvaria starki), and Harris (1958), studying Ocnerostoma piniariella, a needle miner of white pine, in which adults emerge from needles high in the tree crown, and these same needle miners are more dense in the upper tree crown. Field observations by the study authors and others have revealed adult arborvitae leafminers tend to fly briefly in a cloud no more than two to four meters off the ground, and then settle within a minute or so on the host tree or nearby vegetation (Busck 1907; Maier et al. 2011). It is possible that adult female ALMs, being weak fliers, may tend to oviposit at plant canopy levels as high or higher, from which they emerge, congregate, and rest. In addition, ALM adults emerging from mines higher on the plant may find sunny portions and congregation of adults more attractive for mating and oviposition. Additional studies are needed to support and confirm Brown et al.s (1997) hypothesis on lack of movement and egg depletion.

In this study, it appears that canopy aspect was not a major factor in plant susceptibility; no significant differences in damage level were associated with cardinal direction. However, the findings are 
not completely consistent with other leafminer studies and/or other ALM field observations. Miller and Ware (2014) found no significant biological difference in mean percent leaf area consumed by canopy aspect for elm trees by the elm leafminer. In contrast, Davidson and Raupp (2010) advised monitoring for ALM by looking on the south side of the plants, where damage is heavier and damage is first seen in full sun. Exposure and plant age may also be a factor affecting severity of damage. Cloyd (2001) stated that ALM is attracted to Thuja planted in shady locations. He suggested locating plants in sun to help alleviate ALM defoliation problems. Hanson and Walker (2015) mentioned ALM is mostly attracted to older, slow-growing trees exposed to sunlight. Further studies are needed to better understand the relationship between canopy aspect in ALM ovipositional preference and subsequent larval feeding damage.

In the current study, no clear association between foliage color and infestation level was observed. While cultivars 'Aurea' and 'Douglasii Aurea' had yellow foliage and had high amounts of branch tip damage, similar levels of infestation were also seen in green cultivars ('Smaragd') and both species. Previous studies on other insect herbivores have been less than consistent regarding ovipositional preference, leaf color, and larval suitability. 'Sunburst' honeylocust, a yellow-leaf cultivar, has been found more susceptible to feeding damage by honeylocust plant bug compared to green-leaf cultivars (Cloyd 2008), but Bastian (1988) found no significant difference in mean larval development times of mimosa webworm (Homadaula anisocentra) feeding on the 'Sunburst' and green honeylocust cultivars. In addition, Miller and Hart (1987) found no significant differences in overwintering survival of mimosa webworm pupae when larvae fed on all common varieties of honeylocust, including 'Sunburst.' Further study with a larger range of yellow cultivars might help determine whether foliage color affects ALM ovipositional preference and larval suitability.

While not formally examined in this study, additional factors may influence ovipositional preference and larval success. This can affect the level of larval feeding damage, including but not limited to intra- and interspecific larval competition, biological control by natural enemies, host plant physical and chemical characteristics, plant age, plant condition (stress, nutrition, etc.), and exposure. Discussed here are some field and laboratory observations that may help to partially explain the role of these factors in female ALM ovipositional preference and subsequent plant damage.

Some studies have examined intra- and interspecific larval competition with externally and internally feeding insect herbivores, and the results have been inconsistent (Faeth 1991; Barrett 1994; Kagata and Ohgushi 2001; Cornelissen and Stiling 2006). In this study, neither intraspecific nor interspecific larval competition appears to affect larval development, survival, and subsequent feeding damage. Lepidopteran leafminers can detect the presence of conspecific eggs (Simberloff and Stiling 1988; Auerbach and Simberloff 1989), and this behavior could be present with adult female ALMs, thus mitigating intraspecific competition. Informal field and laboratory observations and measurements at the time of IBT assessments revealed mined tips on very dense cultivars were approximately one centimeter apart, while mine tips on less dense and sparse canopy cultivars were two to three centimeters apart. In this study, dissection of mines during IBT damage assessments consistently found only one ALM larva per mine, with more than one larva per mine in very rare cases. While not fully investigated in this study, the difference in branch tip spacing between very dense $(1 \mathrm{~cm})$ and sparse $(2$ to $3 \mathrm{~cm}$ ) canopy species/cultivars might be partially responsible for lower levels of IBTs on very dense plants due to the ability of the ALM female to detect the presence of conspecific eggs, mitigating intraspecific larval competition.

The evergreen bagworm (Thyridopteryx ephemeraeformis), Fletcher scale (Parthenolecanium fletcheri), and two-spotted spider mite (Tetranychus urticae) are common leaf-feeding and sap-feeding pests of arborvitae. At least in this study, none of these pests were present and were not in competition with ALM larvae for plant resources indicating a lack of interspecific competition. However, this may not necessarily be true in other cases.

Over the course of this study, biological control by natural enemies did not appear to be an impor- 
tant factor in regulating ALM populations. While no infested mined leaf tips were held to check for parasitism, a visual examination of mined leaf tips and larvae during two IBT assessments in autumn-winter 2000-2001, and late-summer 2001, did not reveal evidence of parasitism, and no parasitoids were found associated with ALM larval mines over two successive ALM generations.

Van Driesche et al. (1996) noted two species of parasitoids, Pentacnemus bucculatricis and Apanteles dedelliae, associated with ALM in Connecticut, U.S. (Britton and Zappe 1922). In Quebec, Canada, Juillet (1972) recorded 26 species of parasitoids collectively destroying 50\% of several species of arborvitae leafminers. In addition, a study by Bazinet and Sears (1979) found seven parasitoids species caused 9\%-18\% mortality of ALM, but their impact was reduced due to 63\% winter-related mortality in 1977.

It is highly probable that other morphological and/or chemical plant characteristics may be responsible for making these very dense plants less favorable or desirable, but their investigation was beyond the scope of this study.

Results from the current study suggest some important guidelines for ALM management useful to arborists, urban foresters, landscape professionals, and nursery growers. First, while ALM can be a serious defoliator of arborvitae, and early detection and management is critical for overall plant health, some varieties appear to be more affected than others, and there may be different tolerances for damage depending upon a given situation (e.g., plants grown in a nursery for sale versus those in established landscapes). A study by Raupp et al. (1988) on bagworm defoliation on American arborvitae to determine aesthetic injury levels (AIL) and economic injury levels found $50 \%$ of observers perceived damage at $8 \%$ defoliation and discoloration. Further, Koehler and Moore (1983) examined the relationship between density of cypress tip miner leafminer as an indicator of aesthetic injury using an "unsightliness rating" as one of the first attempts at quantifying the relationship between pest abundance and aesthetic quality of a landscape plant. Weston (2008) calculated woody plant pest indexes incorporating detectability, damage potential, and ease of control, with leafminers falling in the moder- ate range with suggested treatment thresholds of $50 \%$ of leaves infested. He based his leafminer threshold on the notion that $25 \%-50 \%$ defoliation can be tolerated by a woody plant before damage is done. However, he did not distinguish between leafminers feeding on deciduous and evergreen plants. The authors of the current study did not conduct a formal analysis of "unsightliness" or conduct a formal damage assessment; the authors did receive verbal communication from The Morton Arboretum's Manager of Plant Collections conveying his concern over the level of plant damage on the arborvitae study plants (K. Bachtell, personal communication). In the current study, this suggests an AIL had been approached, if not exceeded; two cultivars ('Hetz Midget' and 'Hoopesii') were below the $8 \%$ defoliationdiscoloration level identified by Raupp et al. (1988). According to Raupp et al. (1988), evergreen plants (i.e., arborvitae) can tolerate up to $20 \%$ defoliation, and entirely re-foliate in one to two years. Using a suggested AIL of $20 \%$ defoliation, an additional five species/cultivars would probably not require plant protection treatments. The remaining nine species/cultivars with IBTs $>20 \%$ would require some type of appropriate control measures.

Second, when selecting arborvitae for the landscape and/or for managing existing plants, selecting and incorporating short, dense, and globe-shaped arborvitae species/cultivars may be less prone to ALM feeding damage compared to taller, columnar, and pyramidal-shaped trees.

Third, when monitoring for ALM, visually assessing and/or sampling from the upper canopy on shorter plants, and the lower and middle canopy areas of larger trees, will provide an accurate assessment of ALM population levels and potential plant damage. Scouting for IBTs would best be performed in spring, prior to adult emergence in preparation for adult foliar sprays, if warranted, or in late-summer to early-autumn, when most leafmining activity has peaked.

Fourth, examining any aspect $(\mathrm{N}, \mathrm{S}, \mathrm{E}, \mathrm{W})$ of the tree canopy should provide an accurate assessment of existing feeding damage.

Fifth, biological control may not always be a reliable management tactic as seen in this study. Finally, because of ALMs univoltine life cycle, and late-summer and early-spring larval feeding, 
premature leaf abscission will not be a major larval mortality factor as seen with other univoltine or bivoltine deciduous plant feeding leafminers.

In conclusion, it is recognized that this study only looked at susceptibility of arborvitae cultivars for ALM and not ovipositional preference and associated insect-plant relationships. The authors further recognize that observations and conclusions in this study are limited by the small number of available plants per cultivar available for study. Additional laboratory and field studies are needed to better examine the role(s) of plant growth habit, plant nutrition, environment, production of defensive chemicals and plant genetics, natural enemies, and female ovipositional searching behavior in ALM population dynamics. Further information is also needed on the susceptibility of other common plant cultivars, such as 'Green Giant', and ovipositional and feeding preference of other arborvitae leafmining species.

Information gathered from these studies will provide even more reliable, accurate, and efficient management practices improving ALM pest management.

Acknowledgments. The authors wish to sincerely thank Ms. Lisa Nakamoto, Research Intern, The Morton Arboretum, for her help in field sampling and data analysis. A special note of thanks is due to Ms. Brande Overbey, Research Intern, The Morton Arboretum, for her patience and invaluable assistance with data entry and manuscript formatting.

\section{LITERATURE CITED}

Adams, N.E. 2015. Using degree days for insect management. University of New Hampshire Cooperative Extension.

Auerbach, M.J., E.F. Connor, and S. Mopper. 1995. Minor miners and major miner: Population dynamics of leaf-mining insects. pp. 83-110. In: N. Cappuccino and P.W. Price (Eds.). Population Dynamics-New Approaches and Synthesis. Academic Press, New York, New York, U.S.

Auerbach, M.J., and D.J. Simberloff. 1989. Oviposition site preference and larval mortality in a leaf-mining moth. Ecological Entomology 14:131-140.

Barrett, B.A. 1994. Within-tree distribution of Phyllonorycter blancardella (F.) and P. crataegella (Clemens) (Lepidoptera: Gracillariidae) and associated levels of parasitism in commercial apple orchards. Biological Control 4:74-79.

Bastian, R.A. 1988. Influence of temperature, host cultivar, and parasitism on mimosa webworm biology (doctoral dissertation). Iowa State University, Ames, Iowa.

Bazinet, N.L., and M.K. Sears. 1979. Factors affecting the mortality of leafminers, Argyresthia thuiella and Pulicalvaria thujaella
(Lepidoptera: Yponomeutidae and Gelechiidae) on eastern white cedar, in Ontario. Canadian Entomologist 111:1299-1306.

Bentz, J. 2003. Shading induced variability in azalea mediates its suitability as a host for the azalea lace bug. Journal of the American Society for Horticultural Science 128(4):497-503.

Britton, W.E., and M.P. Zappe. 1922. An outbreak of the arborvitae leaf miner, Argyresthia thuiella, Packard. Connecticut Agriculture Experiment Station, New Haven. Bulletin 234:157-160.

Brown, J.L., S. Vargo, E.F. Connor, and M.S. Nuckols. 1997. Causes of vertical stratification in the density of Cameraria hamadryadella (Lepidoptera: Gracillariidae). Ecological Entomology 22:16-25.

Bultman, T.L., and S.H. Faeth. 1988. Abundance and mortality of leafminers on artificially shaded Emory oak. Ecological Entomology 13:131-142.

Busck, A. 1907. Revision of the American moths of the genus Argyresthia. Proceedings of the United States National Museum 32:5-24.

Cloyd, R.A. 2001. Arborvitae Leafminer. College of Agriculture Consumer and Environmental Science. University of Illinois at Urbana-Champaign. INHS.

Collinge, S.K., and S.M. Louda. 1988. Herbivory by leaf miners in response to experimental shading of a native crucifer. Oecologia 75:559-566.

Collinge, S.K., and S.M. Louda. 1989. Scaptomyza nigrita Wheeler (Diptera: Drosophilidae), a leafminer of the native crucifer, Cardamine cordifolia A. Gray (Bittercress). Journal of the Kansas Entomological Society 62:1-10.

Connor, E.F., and M.P. Taverner. 1997. The evolution and adaptive significance of the leaf-mining habit. Oikos 76:6-25.

Connor, E.F. 2006. Effects of the light environment on oviposition preference and survival of a leaf-mining moth, Cameraria hamadryadella (Lepidoptera: Gracillariidae) on Quercus alba L. Ecological Entomology 31:179-184.

Cornelissen, T., and P. Stiling. 2008. Clumped distribution of oak leaf miners between and within plants. Basic and Applied Ecology 9:67-77.

Cornell Extension. 2012. Arborvitae Leafminers. Cornell University Extension of Suffolk County.

Cranshaw, W. 2004. Garden Insects of North America. Princeton University Press, Princeton, New Jersey, U.S. 656 pp.

Davidson, J.A., and M.J. Raupp. 2010. Managing Insects and Mites on Woody Plants: An IPM Approach, second edition. TCIA, Londonberry, New Hampshire, U.S. pp. 26-27, 44.

Dirr, M.A. 2009. Manual of Woody Landscape Plants: Their Identification, Ornamental Characteristics, Culture, Propagation, and Uses, sixth edition. Stipes Publishing Inc., Champaign, Illinois. pp. 1133-1143.

Faeth, S.H. 1991. Novel Aspects of Host Tree Resistance to Leafminers. In: Forest Insect Guilds: Patterns of Interaction with Host Trees. USDA-FS General Technical Report NE-153.

Hanson, T., and E.B. Walker. 2015. Arborvitae Leafminer: Field Guide to Common Insect Pests of Urban Trees in the Northeast. Waterbury, VT: Department of Forests, Parks, and Recreation.

Harris, P. 1958. Life-history and natural control in British Columbia of Ocnerostoma piniariella Zell. (Lepidoptera: Yponomeutidae), a needle miner on white pine. Canadian Entomologist 90:627-631. 
Jandel Scientific. 1992. SigmaStat for Windows. San Rafael, California, U.S. 232 pp.

Juillet, J. 1972. Study of biotic agents in the suppression of certain insect enemies of forests. Annals of Entomological Society of Quebec 17:26-28. (in French)

Kagata, H., and T. Ohgushi. 2001. Preference and performance linkage of a leaf-mining moth on different Salicaceae species. Population Ecology 43:141-147.

Koehler, C.S., and W.S. Moore. 1983. Resistance of several members of the Cupressaceae to the cypress tip miner, Argyresthia cupressella. Journal of Environmental Horticulture 1:87-88.

Maier, C.T., C.R. Lemmon, J.M. Fengler, D.F. Schweitzer, R.C. Reardon. 2011. Caterpillars on the foliage of conifers in the northeastern United States. USDA FHTET-20-07:21.

Miller, F.D., and E.R. Hart. 1987. Overwintering survivorship of pupae of the mimosa webworm, Homadaula anisocentra, (Lepidoptera: Plutellidae) in an urban landscape. Ecological Entomology 12(1):41-50.

Miller, F., and G. Ware. 2014. Seasonal activity, within-tree distribution, and ovipositional and feeding preference of the elm leafminer, Fenusa ulmi (Hymenoptera: Tenethredinidae). Journal of Environmental Horticulture 32(1):39-48.

Moore, L.V., J.H. Myers, and R. Eng. 1988. Western tent caterpillars prefer the sunny side of the tree, but why? Oikos 51:321-326.

North Carolina State University. 2015. Arborvitae Leafminer. Center for IPM, NCSU.

Potter, D.A. 1992. Abundance and mortality of a specialist leafminer in response to experimental shading and fertilization of American holly. Oecologia 91:14-22.

Pottinger, R.P., and E.J. LeRoux. 1971. The biology and dynamics of Lithocolletis blancardella (Lepidoptera: Gracillariidae) on apple in Quebec. Memoirs of the Entomological Society of Canada 77.

Raupp, M.J., J.A. Davidson, C.S. Koehler, C.S. Sadof, and K. Reichelderfer. 1988. Decision-making considerations for aesthetic damage caused by pests. Bulletin of the ESA, Spring 27-32.

Rose, A.H., and O.H. Lindquist. 1982. Insects of Eastern Hardwood Trees. Canadian Forestry Services, Sault Ste. Marie, Ontario, Canada. 304 pp.

Simberloff, D., and P. Stiling. 1988. Larval dispersion and survivorship in a leaf-mining moth. Ecology 69:1647-1657.

Stark, R.W. 1952. Analysis of a population sampling method for the lodgepole needle miner in Canadian Rocky Mountain Parks. Canadian Entomologist 84:316-321.

Stark, R.W. 1958. Life tables for the lodgepole needle miner, Recurvaria starki Free (Lepidoptera: Gelechiidae). Proceedings of the Tenth International Congress of Entomology 4:964-967.

Trumbule, R.B., and R.F. Denno. 1995. Light intensity, host plant irrigation, and habitat-related mortality as determinants of the abundance of azalea lace bug (Heteroptera: Tingidae). Environmental Entomology 24:898-908.

Van Driesche, R.G., S. Healy, and R.C. Readon. 1996. Biological control of arthropod pests of the northeastern and north central forests in the United States: A review and recommendations. USDA-FS, FHTET-96-19. pp. 148-149.

Weston, P.A. 2008. Pest index: A new approach to establishing thresholds for pest management in woody landscape plants. Journal of Environmental Horticulture 26:58-62.
Fredric Miller (corresponding author)

Senior Research Scientist-Entomology

The Morton Arboretum

Lisle, Illinois, U.S.

\author{
Donna Danielson \\ Instructor \\ College of DuPage \\ Glen Ellyn, Illinois, U.S.
}

Résumé. Dix-huit espèces et cultivars de thuya furent évalués quant à leur préférence par la mineuse du thuya pour l'oviposition (dépôt des œufs) ainsi que pour son alimentation et par conséquent, afin d'établir leur sensibilité relative à l'infestation de cet insecte. Le Thuja occidentalis 'Hetz Midget' et le 'Hoopesii' étaient les moins sensibles; les T. occidentalis 'Holmstrup', T. plicata 'Fastigiata', T. occidentalis 'Spiralis', 'Gracilis' et 'Techny' ont démontré une sensibilité intermédiaire; tandis que les cultivars du Thuja occidentalis 'Aurea', 'Douglasii Aurea', 'Globosa', 'Hetz Wintergreen', 'Wagneri', 'Wareana', T. plicata, T. occidentalis et les cultivars T. occidentalis 'Umbraculifera' et 'Waxen' et 'Smaragd' se sont tous avérés très sensibles à la mineuse du thuya. Les arbres plus courts ont subi significativement moins de dommages que les grands arbres, le nombre de pointes de branches infestées (PBI) augmentait avec la hauteur des arbres. Les arbres plus courts $(<4 \mathrm{~m})$ présentaient significativement plus de dégâts au niveau de leur cime, tandis que les grands arbres $(>4 \mathrm{~m})$ présentaient plus de dégâts dans les parties médiane et basse des houppiers. Les arbres avec des houppiers très denses avaient significativement moins de PBI par rapport aux arbres aux houppiers clairsemés, moyens et denses, les PBI diminuant à mesure que la densité du houppier augmentait. Il n'y avait pas d'associations significatives entre le nombre de PBI et l'aspect du houppier. La hauteur de la plante, le mode de croissance ainsi que la portion et la densité du houppier semblent influencer le niveau d'infestation et éventuellement la préférence ovipositionnelle. Ces résultats suggèrent quelques importantes lignes directrices pour la gestion de la mineuse du thuya en ce qui concerne les pépinières et les entreprises en aménagement et entretien paysager.

Zusammenfassung. Achtzehn Thuja-Arten und Kultivare wurden hinsichtlich der Eiablage-Präferenz und der relativen Anfälligkeit durch die Thujaminiermotte gefressen zu werden, bewertet. Thuja occidentalis 'Hetz Midget' und 'Hoopesii' waren am wenigsten anfällig; T. occidentalis 'Holmstrup', T. plicata 'Fastigiata', T. occidentalis 'Spiralis', 'Gracilis', und 'Techny' waren mittelmäßig anfällig; Thuja occidentalis cultivars 'Aurea', 'Douglasii Aurea', 'Globosa', 'Hetz Wintergreen', 'Wagneri', 'Wareana', T. plicata, T. occidentalis, und T. occidentalis Kultivare 'Umbraculifera' und 'Waxen' und Thuja occidentalis 'Smaragd' waren hochgradig anfällig für eine Freßattacke durch die Thujaminiermotte. Kurze erlitten deutlich weniger Attacken als hohe Bäume, wobei die Anzahl der infizierten Zweigspitzen mit der Baumhöhe zunahm. Kurze Bäume $(>4 \mathrm{~m})$ hatten deutlich mehr Fraßschäden in der oberen Krone und größere Bäume $(<4 \mathrm{~m})$ hatten größeren Schaden in den mittleren und unteren Kronenbereichen. Bäume mit sehr dichten Kronen hatten deutlich weniger infizierte Triebspitzen im Vergleich zu Bäumen mit lockeren, mittleren und dichten Kronen, wobei die Anzahl der infizierten Triebspitzen mit zunehmender Kronendichte abnahm. Es gab keine signifikanten Assoziationen zwischen infizierten Triebspitzen und dem Kronenzustand. Die Höhe der Pflanzen, Wachstumsform und Kronenbereich und Dichte scheinen den Level an Infestationen und möglicherweise die Eiablagepräferenzen 
zu beeinflussen. Die Ergebnisse schlagen einige wichtige Management-Richtlinien für die Thujaminiermotte in Baumschulen und der Landschaftsbauindustrie vor.

Resumen. Se evaluaron dieciocho especies y cultivares de Thuja para conocer la preferencia oviposicional y la susceptibilidad relativa a la alimentación por el minador de hojas. Thuja occidentalis 'Hetz Midget' y 'Hoopesii' fueron los menos susceptibles; T. occidentalis 'Holmstrup', T. plicata 'Fastigiata', T. occidentalis 'Spiralis', 'Gracilis' y 'Techny' fueron intermedios en susceptibilidad; los cultivares de Thuja occidentalis 'Aurea', 'Douglasii Aurea', 'Globosa', 'Hetz Wintergreen', 'Wagneri', 'Wareana', T. plicata, T. occidentalis y T. occidentalis 'Umbraculifera' y 'Waxen' y Thuja occidentalis 'Smaragd' fueron altamente susceptibles al minador. Los árboles chicos sufrieron significativamente menos daño en comparación con los árboles mayores, con el número de ramas infestadas (IBT) aumentando con la altura del árbol. Los árboles chicos $(<4 \mathrm{~m})$ tuvieron significativamente más daño en la zona superior del dosel y los árboles altos (> $4 \mathrm{~m}$ ) tuvieron mayor daño en las zonas inferior y media. Los árboles con copas muy densas tuvieron significativamente menos IBTs en comparación con árboles con doseles escasos, medios y densos, con IBTs disminuyendo a medida que aumentaba la densidad del dosel. No hubo asociaciones significativas entre el número de IBTs y el aspecto del dosel. La altura de la planta, el hábito de crecimiento y la zona y densidad del dosel parecen influir en el nivel de infestación y, posiblemente, en la preferencia oviposicional. Estos hallazgos sugieren algunas directrices importantes de manejo de ALM para las industrias de vivero y paisajismo. 